\title{
Unravelling the Potential of Lactococcus lactis Strains to Be Used in Cheesemaking Production as Biocontrol Agents
}

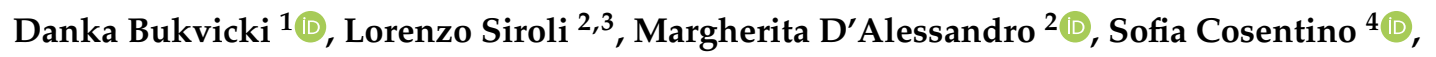 \\ Ismail Fliss ${ }^{5}$, Laila Ben Said ${ }^{5}$, Hebatoallah Hassan ${ }^{4}$, Rosalba Lanciotti ${ }^{2,3}$ and \\ Francesca Patrignani $2,3, *$ (D)
}

1 Department of Morphology and Systematics of Plants, Faculty of Biology, Institute of Botany and Botanical Garden "Jevremovac", University of Belgrade, Takovska 43, 11000 Belgrade, Serbia; dankabukvicki@gmail.com

2 Department of Agricultural and Food Sciences, University of Bologna, p.zza Goidanich 60, 47521 Cesena, Italy; lorenzo.siroli2@unibo.it (L.S.); margheri.dalessandr3@unibo.it (M.D.); rosalba.lanciotti@unibo.it (R.L.)

3 Interdepartmental Center for Industrial Agri-Food Research, University of Bologna, Piazza Goidanich 60, 47521 Cesena (FC), Italy

4 Department of Medical Sciences and Public Health, University of Cagliari, 09042 Monserrato, Italy; scosenti@unica.it (S.C.); hebatoallah.hassan.1@ulaval.ca (H.H.)

5 Food Science Department, Food and Agriculture Faculty, Institute of Nutrition and Functional Foods, Laval University, 2425 Agriculture Street, Quebec City, QC G1V0A6, Canada; ismail.fliss@fsaa.ulaval.ca (I.F.); laila.ben-said.1@ulaval.ca (L.B.S.)

* Correspondence: francesca.patrignani@unibo.it; Tel.: +39-0547-338133

Received: 16 November 2020; Accepted: 2 December 2020; Published: 7 December 2020

check for updates

\begin{abstract}
This research, developed within an exchange program between Italy and Canada, represents the first step of a three-year project intended to evaluate the potential of nisin-producing Lactococcus lactis strains isolated from Italian and Canadian dairy products to select a consortium of strains to be used as biocontrol agents in Crescenza and Cheddar cheese production. In this framework, the acidification and the production of nisin in milk, and the volatile molecule profiles of the fermented milk, were recorded. The strains were further tested for their anti-Listeria monocytogenes activity in milk. The data obtained highlighted good potential for some of the tested strains, which showed production of nisin beginning within $12 \mathrm{~h}$ after the inoculation and reaching maximum levels between 24 and $48 \mathrm{~h}$. The highest inactivation levels of L. monocytogenes in milk was reached in the presence of the strains 101877/1, LBG2, 9FS16, 11FS16, 3LC39, FBG1P, UL36, UL720, UL35. The strains generated in milk-specific volatile profiles and differences in the presence of fundamental aromatic molecules of dairy products, such as 2-butanone and diacetyl. The results highlight the interesting potential of some L. lactis strains, the producer of nisin, to be further used as biocontrol agents, although the strains need to be tested for interaction with traditional thermophilic starters and tested in real cheesemaking conditions.
\end{abstract}

Keywords: Lactococcus lactis; milk; nisin; volatile compounds; Listeria monocytogenes; antimicrobial activity

\section{Introduction}

Cheeses and dairy products are widely consumed, and they represent one of the fastest growing sectors within the food industry [1,2]. In specific cases, some types of cheese are susceptible to 
microbial spoilage and they can also be carriers of foodborne pathogenic species deriving from raw milk. In fact, sometimes, these microorganisms can be resistant to the pasteurization process of the milk and survive in the final product. Many attempts have been made to reduce the incidence of pathogenic and spoilage agents, including using chemical additives, which are usually perceived negatively by consumers [3]. To solve this challenge, in the past few decades, industrial and academic research has focused its attention on natural antimicrobials since the expectations of consumers toward natural products have increased significantly. In the dairy industry, this outcome can be achieved by the use of natural antimicrobial compounds produced in situ by lactic acid bacteria (LAB) [4]. In fact, LABs can produce many antimicrobial molecules such as organic acids, diacetyl, hydrogen peroxide, peptides with antifungal action and bacteriocins $[5,6]$. Bacteriocins, short peptides with a low molecular weight, are considered safe food biopreservatives because they are simply degraded in the human gastrointestinal tract and do not negatively impact the gut microbiota [7-10]. Production of bacteriocins by LAB could be important to manage and reduce the growth of food pathogens and spoilage bacteria in food [4]. Nevertheless, some limiting factors such as absorption of food components, enzymatic degradation, and poor solubility need to be taken into consideration [10]. Among LAB, Lactococcus lactis is one of the most frequently researched species due to its aptitude to produce nisin, a bacteriocin largely studied in different foods for its wide antimicrobial spectrum [11]. In particular, nisin is especially effective against Gram-positive bacteria such as Listeria monocytogenes, Clostridium spp., and Staphyloccoccus aureus [12-15]. The effectiveness of nisin has been demonstrated in vitro and in situ $[12,14]$ including vegetable-based juices and beverages [13,15], fermented vegetable products [16], as well as meat-based foods [17]. This bacteriocin, and particularly the variant $Z$, is very soluble and stable at high temperatures and in acidic environments [10]. Although its antimicrobial activity has been well tested, the European Food Safety Authority (EFSA) only allows its use as a biopreservative (E234) in a few foods (cheeses like mascarpone and some egg-based preparations). Due to several strict regulations, the dairy industry is interested in searching for nisin-producing L. lactis strains to be used as a biopreservation strategy as a part of the fermentation process or as adjuvant cultures [10]. For the dairy industry, this represents a great advantage since L. lactis is widely used as starter, and/or co-starter for several cheese productions, including Cheddar and Crescenza $[18,19]$. Moreover, the incorporation of nisin-producing L. lactis strains could also be a strategy to increase the desirable sensory features of the final dairy products. However, for this purpose, the selection of suitable L. lactis strains needs to take into account some important safety and technological considerations, such as the strain's antibiotic resistance [20,21], the strain's ability to quickly ferment the substrate and produce acid (in case it is used as a starter), to impart good sensory properties, and to inhibit the growth of pathogenic microorganisms (especially if used as biocontrol agents) $[10,21]$.

In this framework, the main objective of the present study, developed by an exchange program between Italy and Quebec, was to characterize selected L. lactis strains, isolated from Italian and Canadian dairy products in order to use some of them as potential protective cultures in cheesemaking to produce Cheddar (hard cheese) or Crescenza (soft cheese). Twenty strains from two geographical origins (Italy and Canada) were screened for (some) important technological traits and their ability to generate volatile molecule profiles in milk at two different incubation temperatures. Additionally, in order to select good biocontrol agents, the nisin production over the incubation and the ability to inhibit Listeria monocytogenes in skim milk were also screened for all the strains.

\section{Materials and Methods}

\subsection{Bacterial Strains and Culture Media}

The strains employed in this research belong to the collection of the Department of Agricultural and Food Sciences (University of Bologna), the Department of Public Health, Clinical and Molecular Medicine (University of Cagliari) and STELA research center (Universite Laval, Quebec, QC, Canada) as reported by Table 1 . The strains were isolated from different dairy products and were already 
identified as having the gene-encoding nisin. All the strains were maintained at $-80^{\circ} \mathrm{C}$ in $\mathrm{M} 17$ medium (Oxoid, Milan, Italy) supplemented with 30\% glycerol prior to their use (Sigma Aldrich, Milan, Italy). They were also grown twice in M17 medium (Oxoid, Milan, Italy) for $24 \mathrm{~h}$ at $30{ }^{\circ} \mathrm{C}$ under aerobic conditions before being used.

Table 1. Lactococcus lactis strains used in the research.

\begin{tabular}{|c|c|c|c|c|}
\hline Strains & Species & Isolation Source & Produced Nisin & Collection \\
\hline \multicolumn{5}{|c|}{ Italian strains } \\
\hline 3LC39 & Lactococcus lactis subsp. lactis & Goat milk & A & UNIBO \\
\hline LSGA1B & Lactococcus lactis subsp. lactis & Raw Cow milk & $*$ & UNIBO \\
\hline 9/20234 & Lactococcus lactis subsp. lactis & Sheep milk & A & UNICA \\
\hline LSG3 & Lactococcus lactis subsp. lactis & Raw Cow milk & * & UNIBO \\
\hline $10 / 18771$ & Lactococcus lactis subsp. lactis & Sheep milk & A & UNICA \\
\hline LBG2 & Lactococcus lactis subsp. lactis & Cow milk & * & UNIBO \\
\hline 9FS16 & Lactococcus lactis subsp. lactis & Fiore Sardo cheese & A & UNICA \\
\hline 1LC18 & Lactococcus lactis subsp. lactis & Goat milk & A & UNICA \\
\hline 6MRSL55 & Lactococcus lactis subsp. lactis & Sheep's milk & $\mathrm{Z}$ & UNICA \\
\hline $6 / 23898$ & Lactococcus lactis subsp. lactis & Sheep milk & A & UNICA \\
\hline \multicolumn{5}{|c|}{ Canadian strains } \\
\hline UL719 & Lactococcus lactis subsp. lactis biovar diacetylactis & Cheddar cheese & $\mathrm{Z}$ & STELA \\
\hline UL720 & Lactococcus lactis subsp. lactis biovar diacetylactis & Cheddar cheese & $\mathrm{Z}$ & STELA \\
\hline UL730 & Lactococcus lactis subsp. lactis biovar diacetylactis & Cheddar cheese & Z & STELA \\
\hline
\end{tabular}

${ }^{*}$ To be verified in the present research.

\subsection{Detection of Nisin Encoding Gene}

For the strains belonging to the University of Bologna collection, total genomic DNA was extracted from L. lactis cells and purified using the InstaGene matrix mix (Bio-Rad laboratories, Milano, Italy), following the manufacturer's recommendations. In the analysis, a negative control and strains encoding for nisin Z (L. lactis CBM21, [22]) and nisin A (L. lactis ATCC11454, [23]) as positive controls were used. The amplification of the nisin-encoding gene was performed by using the primers reported by De Vos et al. [24] (forward: 5'-CGCGAGCATAATAAACGGCT-3'; reverse: 5'-GGATAGTATCCATGTCTGAAC-3'). The composition of the PCR mixture $(50 \mu \mathrm{L})$ was the following: $2 \mathrm{mM} \mathrm{MgCl} 2,0.2 \mu \mathrm{M}$ of each primer, $0.2 \mathrm{mM}$ of deoxyribonucleotide triphosphates (dNTPs), $0.02 \mathrm{U} / \mu \mathrm{L}$ Taq polymerase, $1 \times$ PCR buffer, and approximately $20 \mathrm{ng}$ of genomic DNA [22]. The thermocycling conditions were the following: denaturation at $94{ }^{\circ} \mathrm{C}$ for $5 \mathrm{~min} ; 30$ cycles at $93^{\circ} \mathrm{C}$ for $2 \mathrm{~min}, 54{ }^{\circ} \mathrm{C}$ for $1 \mathrm{~min}, 72{ }^{\circ} \mathrm{C}$ for $1.5 \mathrm{~min}$, then a final extension at $72{ }^{\circ} \mathrm{C}$ for $10 \mathrm{~min}$. PCR products were visualized on $1.5 \%$ agarose gel. The PCR resulting amplicons were purified with the QIAquick PCR Purification Kit (Qiagen, USA) and sequenced at BMR Genomics sequencing centre (Padua, Italy). Sequences were then compared with those available in GenBank database retrieved through BLASTn searches and then aligned using the GeneDoc 2.7 software as reported by Siroli et al. [22].

\subsection{Fermentation Ability and Acidification in Milk}

The strains were sub-cultured twice in M17 medium at $30{ }^{\circ} \mathrm{C}$ for $24 \mathrm{~h}$ and further inoculated in $100 \mathrm{~mL}$ of commercial UHT whole cow milk at a final concentration of approximately $6 \log \mathrm{cfu} / \mathrm{mL}$ in triplicate. The samples were incubated at 30 and $37^{\circ} \mathrm{C}$. Immediately after inoculation and after 12,24 , 48, and $72 \mathrm{~h}$, the $\mathrm{pH}$ decrease was monitored using 8519 Hanna-Instruments pH-meter (Milan, Italy) and L. lactis cell counts were detected. For this, decimal dilutions were performed in distilled water added of $0.9 \% \mathrm{NaCl}$ and spread onto M17 agar plates added with $0.5 \%$ lactose. The Petri dishes were incubated at $30{ }^{\circ} \mathrm{C}$ for $24-48 \mathrm{~h}$ in aerobic conditions. 


\subsection{Volatile Molecule Profiles of Fermented Samples}

The analysis of volatile molecule profiles was performed by gas chromatography-mass spectrometry (GC/MS) coupled with solid phase micro extraction (SPME). After $72 \mathrm{~h}$ of incubation, milk samples, inoculated with different strains of L. lactis, were analysed according to the method of Patrignani et al. [25]. Briefly, 5 millilitres of sample were put in vials and incubated for $10 \mathrm{~min}$ at $45^{\circ} \mathrm{C}$, then the fibre (CAR/PDMS, $75 \mu \mathrm{m}$, SUPELCO, Bellafonte, PA, USA) was left into the vial head space for $30 \mathrm{~min}$ at $45^{\circ} \mathrm{C}$. The absorbed volatiles were desorbed in the gas chromatograph (GC) injector port in spitless mode at $250^{\circ} \mathrm{C}$ for $10 \mathrm{~min}$. Headspace of the volatile compounds was analysed using Gas-Chromatography (GC) 6890N, Network GC System with mass spectrometry (MS) 5970 MSD (Hewlett-Packard, Geneva, Switzerland). The Chrompack CP-Wax 52 CB $(50 \mathrm{~m} \times 320 \mu \mathrm{m} \times 1.2 \mu \mathrm{m})$ column was used. The initial temperature was $40^{\circ} \mathrm{C}$ for $1 \mathrm{~min}$, and then increased by $4.5^{\circ} \mathrm{C} / \mathrm{min}$ up to $65{ }^{\circ} \mathrm{C}$. Then, temperature increased by $10^{\circ} \mathrm{C} / \mathrm{min}$ up to $230{ }^{\circ} \mathrm{C}$ and remained at this temperature for $17 \mathrm{~min}$. Gas-carrier was helium at $1.0 \mathrm{~mL} / \mathrm{min}$ flow. The different molecules were recognised by comparison based on NIST 11 (National Institute of Standards and Technology) database. Moreover, an internal standard (4-methyl-2-pentanol) was used.

\subsection{Nisin Activity Determination}

The activity of nisin was detected in inoculated commercial skim milk samples during the fermentation at 30 and $37^{\circ} \mathrm{C}$, after $6,12,24,48$, and $72 \mathrm{~h}$ of incubation, in relation to the strain used. Nisin assay was performed by the agar-well diffusion method as described by Pongtharangkul and Demirci [26], Millette et al. [27], and de Oliveira Junior et al. [28] with some modifications. Ten milliliters of the fermented sample were collected, and $\mathrm{pH}$ of the samples was adjusted to 6 with $2 \mathrm{~N} \mathrm{NaOH}$ and then centrifuged at $6000 \mathrm{~g}$ for $20 \mathrm{~min}$. The supernatants were collected and filtered $(0.45 \mu \mathrm{m}$ pore diameter). Next, supernatants were let to boil for $10 \mathrm{~min}$ and then chilled. Wells of $5 \mathrm{~mm}$ diameter were made into each plate and filled with $50 \mu \mathrm{L}$ of the supernatant. Lactobacillus plantarum V7B3 (collection at Department of Agricultural and Food Sciences, University of Bologna, Italy) was used as the nisin-sensitive strain in the study [6]. The strain was grown in de Man, Rogosa, and Sharpe (MRS, Oxoid, Milano, Italy), respectively, for $24 \mathrm{~h}$ at $37^{\circ} \mathrm{C}$. The agar-well diffusion assay was performed in MRS soft agar (0.8\% agar) inoculated with L. plantarum V7B3 at $7.0 \log$ CFU/mL. The zones of inhibition were measured after incubation at $37^{\circ} \mathrm{C}$ for $24 \mathrm{~h}$ and related with standard nisin linear regression equation to obtain final concentrations.

\subsection{Standard Nisin Linear Regression Equation}

A stock solution of nisin was prepared by dissolving commercial nisin 2.5\% (Sigma-Aldrich, Milan, Italy) in $0.02 \mathrm{~N} \mathrm{HCl}$, which had been previously sterilized. Concentrations ranging from 1000 to 0 International Units (IU) $(1000,500,400,300,200,100,50$, and $0 \mathrm{IU} / \mathrm{mL})$ were prepared in skim milk and the nisin activity was plotted against these concentrations to construct the standard curve according to the method previously described using the same substrate and temperature condition. The line regression equation was determined the for standard curve. The activity of nisin expressed in international units per milliliter was converted to $\mathrm{mg} / \mathrm{L}$ through the relation in Equation (1):

$$
\operatorname{nisin}(\mathrm{mg} / \mathrm{L})=(\mathrm{z} \times 0.025),
$$

where $\mathrm{z}=\mathrm{IU} / \mathrm{mL}$ and 0.025 is a conversion value related to $2.5 \%$ pure nisin.

\subsection{Challenge Test in Presence of Listeria Monocytogenes}

The strains were tested to evaluate their ability to inhibit L. monocytogenes in milk at 30 and $37^{\circ} \mathrm{C}$. Lactococcus strains were inoculated at $6.0 \mathrm{log} \mathrm{cfu} / \mathrm{mL}$ in commercial UHT whole milk, while L. monocytogenes (Scott A) was inoculated at $4.0 \log \mathrm{cfu} / \mathrm{mL}$. The samples were performed in triplicates. L. lactis counts were detected on M17 agar supplemented with a solution of lactose $10 \%$ 
(Oxoid, Milan, Italy) while Listeria selective agar base added of Listeria selective supplement (Oxoid) was used for L. monocytogenes counting. Samples were taken at $0,6,12,24,48$, and $72 \mathrm{~h}$ of incubation at 30 and $37^{\circ} \mathrm{C}$.

\subsection{Statistical Analysis}

The data are expressed as the mean of three repetitions and two independent experiments. The cell load and $\mathrm{pH}$ data were considered significantly different $(p<0.05)$ on the basis of ANOVA and TUKEY HSD post hoc. The volatile molecule raw data (expressed as area) were analyzed using ANOVA followed by a principal component analysis (PCA), performed by Statistica software (Stat 5.0 for Windows), to define the effects of the individual strains and the temperature of incubation on the volatile compounds produced.

\section{Results}

\subsection{Detection of Nisin-Encoding Gene}

In order to identify the type of produced nisin for LSGA1B, FBG1P, LBG1G, LSG3, LBG2), a 598-bp fragment was amplified from the genomic DNA of these strains, which was identical to that of nisin-positive control strains L. lactis subsp. lactis ATCC 11454 and L. lactis subsp. lactis CBM21 (Figure not showed).

The sequencing of amplicons resulting from PCR are reported in Figure 1. The sequences, compared with those available in GenBank database retrieved through BLASTn search, confirmed the production of Nisin A for LSGA1B, FBG1P, LBG1G and nisin Z for LSG3, LBG2.

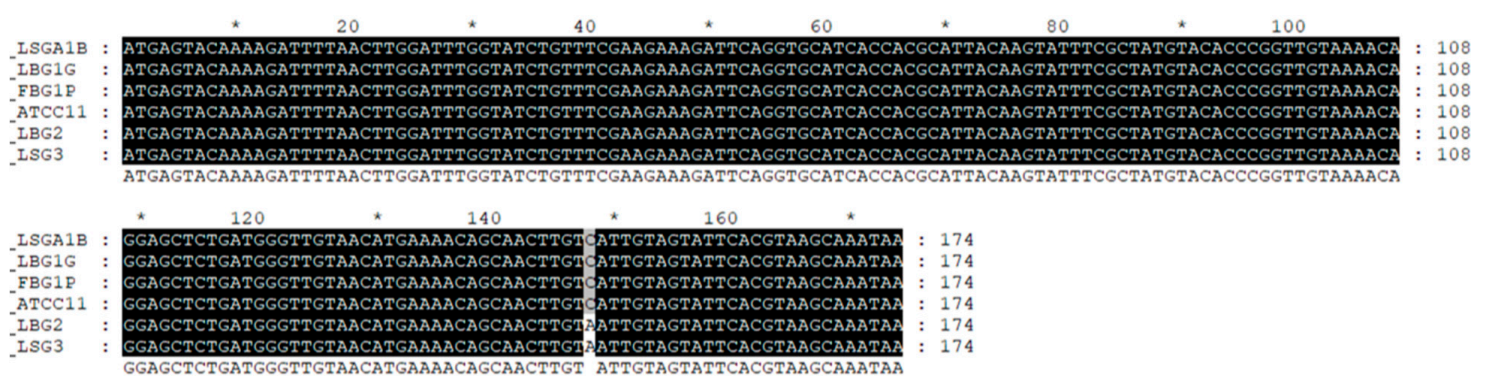

Figure 1. Multiple alignment of amplicon sequences resulting from PCR analysis for the strain of L. lactis FBG1P, LBG1G, LSG3, LBG2, LSGA1B.

\subsection{Lactococcus lactis Growth and Ph Decrease in Whole Milk at 30 and $37^{\circ} \mathrm{C}$}

The growth and the $\mathrm{pH}$ decrease of L. lactis strains in whole commercial UHT cow milk at $37^{\circ} \mathrm{C}$ are put in Figures 2 and 3, respectively. All the strains inoculated in milk at a level between 6.0 and $6.5 \log \mathrm{cfu} / \mathrm{mL}$ were able to reach the maximum cell loads during $12 \mathrm{~h}$ at $37^{\circ} \mathrm{C}$, achieving over $8.0 \log \mathrm{cfu} / \mathrm{mL}$. Only the strain 9FS16 reached cell load values over $8.0 \log \mathrm{cfu} / \mathrm{mL}$ between 48 and $72 \mathrm{~h}$. However, after $72 \mathrm{~h}$ of incubation this strain's growth was not significantly different from that of most of the tested strains. After $72 \mathrm{~h}$ of incubation at $37^{\circ} \mathrm{C}$, among Canadian strains, significant cell load decreases were reached by the strains UL719 and 730. On the other hand, these two strains showed a similar behaviour when incubated at $30{ }^{\circ} \mathrm{C}$ (Figure 4). As reported in Figure 3 , most of the strains were able to reduce the $\mathrm{pH}$ of the milk to levels below 5.0 over $72 \mathrm{~h}$ of incubation at $37^{\circ} \mathrm{C}$. In general, the strains belonging to the collection of STELA were faster with respect to the other strains in the first $12 \mathrm{~h}$ of incubation since they were able to reduce the $\mathrm{pH}$ of milk at levels ranging between 5.51 and 5.79 . 


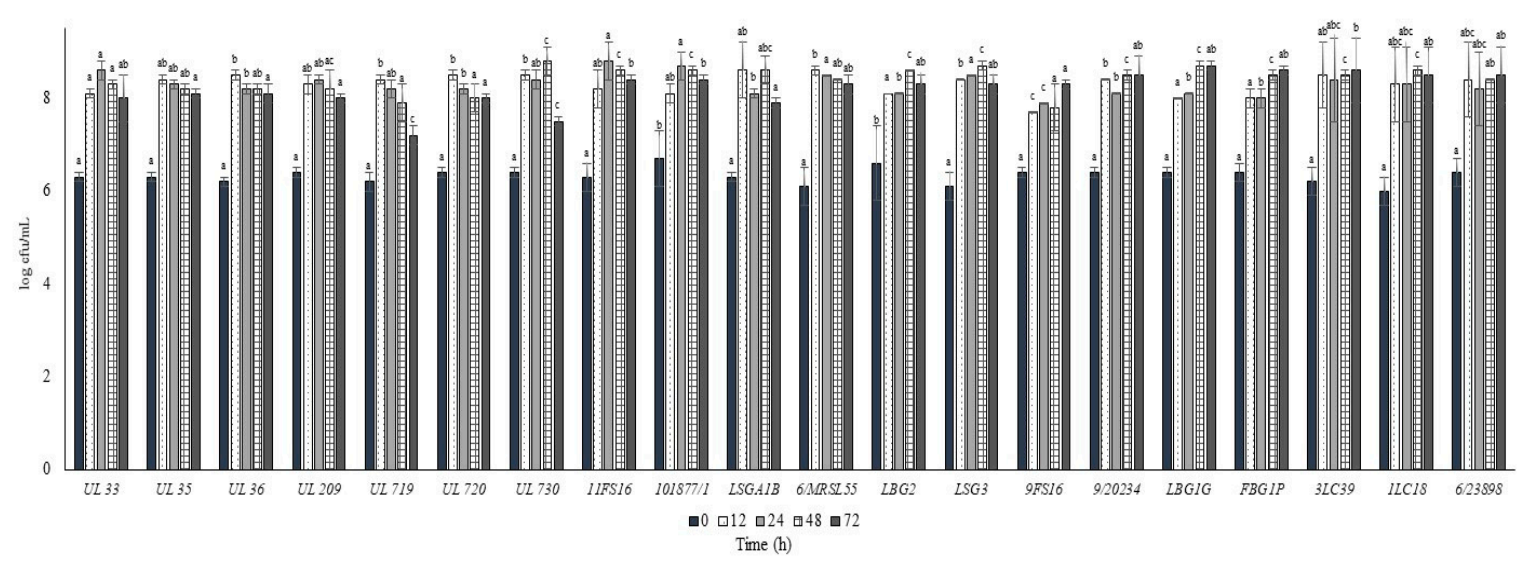

Figure 2. Cell loads (log cfu/mL) of the tested Lactococcus lactis strains in milk over the incubation at $37^{\circ} \mathrm{C}$. For each sampling time considered, samples with a different lowercase letter are significantly different $(p<0.05)$.

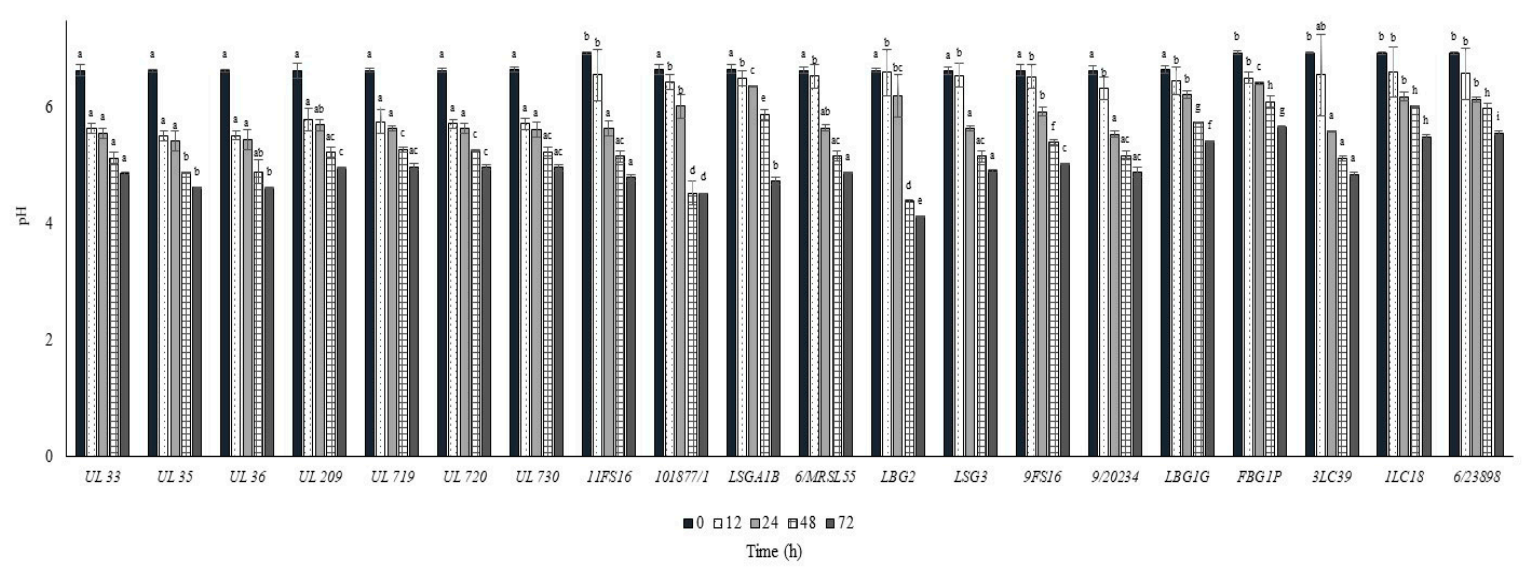

Figure 3. $\mathrm{pH}$ values $\pm \mathrm{SD}$ recorded in milk samples after the inoculum of the Lactococcus lactis strains and the incubation at $37^{\circ} \mathrm{C}$. For each sampling time considered, samples with a different lowercase letter are significantly different $(p<0.05)$.

In Figures 4 and 5, the cell load and the $\mathrm{pH}$ decrease of the L. lactis strains inoculated in cow milk and stored at $30^{\circ} \mathrm{C}$ are reported over time. All the strains reached cell load levels higher than $8.0 \mathrm{log} \mathrm{cfu} / \mathrm{mL}$ within $24 \mathrm{~h}$ except for the strain 9FS16, which had significantly lower levels when compared with the remaining strains. Additionally, in this case, some of the strains from the Canadian collection (UL 36, UL35, UL719, UL720) showed rapid acidification and growth, reaching values of $8 \log \mathrm{cfu} / \mathrm{mL}$ in $12 \mathrm{~h}$. Of note, the strains 6/23898, FBG1P, and LBG2 were able to significantly decrease the $\mathrm{pH}$ of milk below 5.0 in $24 \mathrm{~h}$. 


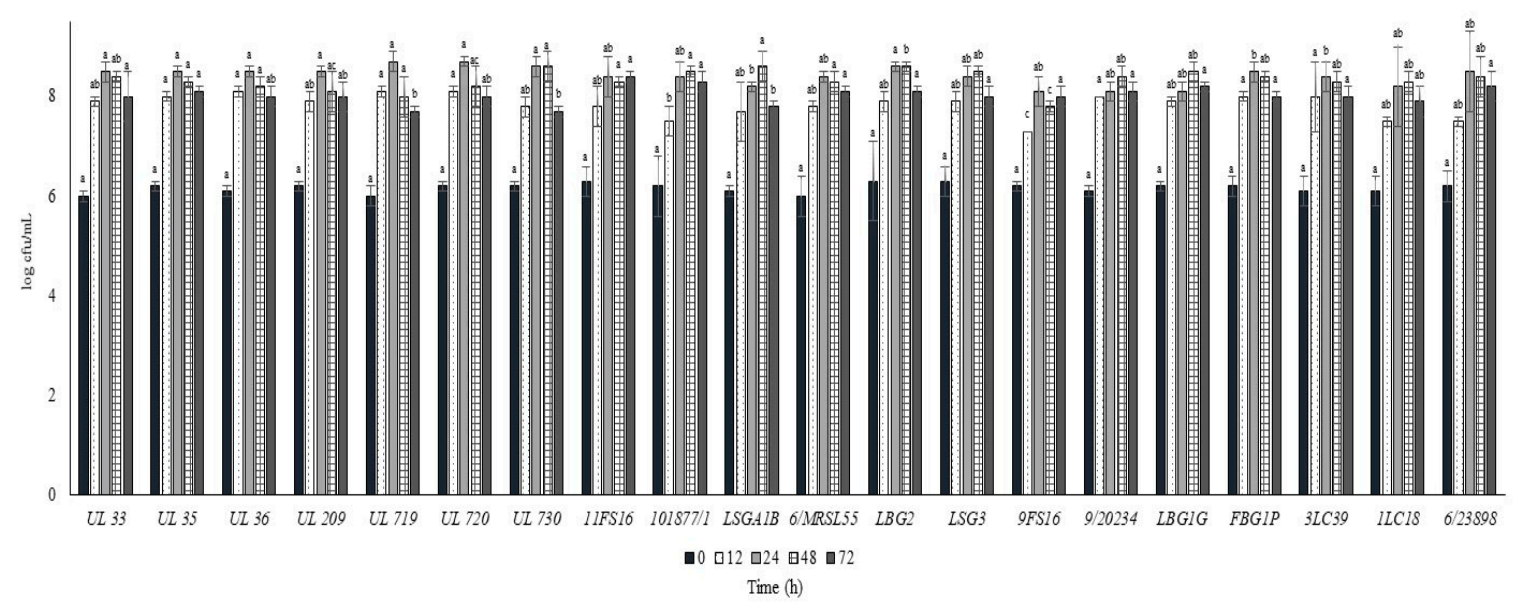

Figure 4. Cell loads (log cfu/mL) of the tested Lactococcus lactis strains in milk over the incubation at $30^{\circ} \mathrm{C}$. For each sampling time considered, samples with a different lowercase letter are significantly different $(p<0.05)$.

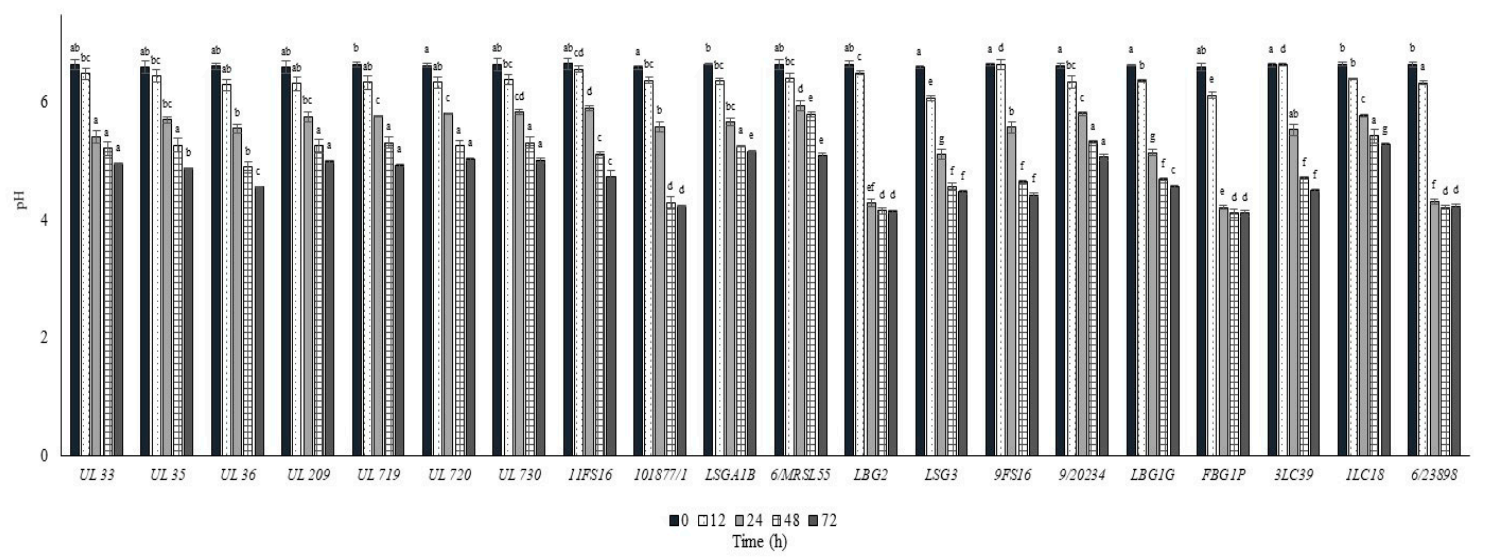

Figure 5. $\mathrm{pH}$ values $\pm \mathrm{SD}$ recorded in milk samples after the inoculum of the L. lactis strains and the incubation at $30^{\circ} \mathrm{C}$. For each sampling time considered, samples with a different lowercase letter are significantly different $(p<0.05)$.

\subsection{Volatile Aroma Profile by GC-MS/SPME at 30 and $37^{\circ} \mathrm{C}$}

The volatile molecule profiles, detected in milk samples by GC-MS/SPME after $72 \mathrm{~h}$ of incubation at 30 and $37^{\circ} \mathrm{C}$, showed different aromagram profiles according to the strain and incubation temperature used. The main chemical classes of compounds were represented by ketones, alcohols, acids, and aldehydes. To highlight the differences in the volatile compound profiles of fermented milks at 37 and $30^{\circ} \mathrm{C}$ in relation to each individual strain, the GC-MS/SPME raw data (expressed as area) were processed by PCA. Data from samples incubated at $37^{\circ} \mathrm{C}$ are reported in Figure $6 \mathrm{a}, \mathrm{b}$, while Figure $7 \mathrm{a}, \mathrm{b}$ shows data from samples incubated at $30^{\circ} \mathrm{C}$. After fermentation at $37^{\circ} \mathrm{C}$, the samples were projected on the factorial plane $(1 \times 2)$ spanned by the first two factors (Factor 1 and Factor 2), which describe 46.83 and $14.1 \%$, respectively, of the total variance among the samples. The separation on the factorial plane was mainly related to the biovar. In fact, strains with Canadian origins were grouped together with the exception of the strain UL 33. The molecules that affected this behavior (as reported in Figure $6 \mathrm{~b}$ ) were mainly 2,3 butanedione, 3-hydroxy2-butanone, 1-heptanone, 2 methyl propanol, and acetic acid. Another group, separated from the previous one along Factor 2, was clearly composed by the metabolites coming from the strains 1LC18, FBG1P, 9FS16, 3LC39, 6/23898, 11FS16, 10/18771, UL33. In this case, 2-butanone, 2-ethyl, decanol, acetone, ethanol, 2-pentanone, 2-Heptanol, 6 methyl, 3-methyl butanal, methyl isobutyl ketone contributed to the grouping. The third group, separated 
from the others, along Factor 1, was represented by the remaining samples whose clusterization was affected by 1 hydroxy- 2 propanone, butanoic acid, decanoic acid, benzenacetaldehyde, 2,6 dimethyl 4 heptanol, 3 methyl decanoic acid.

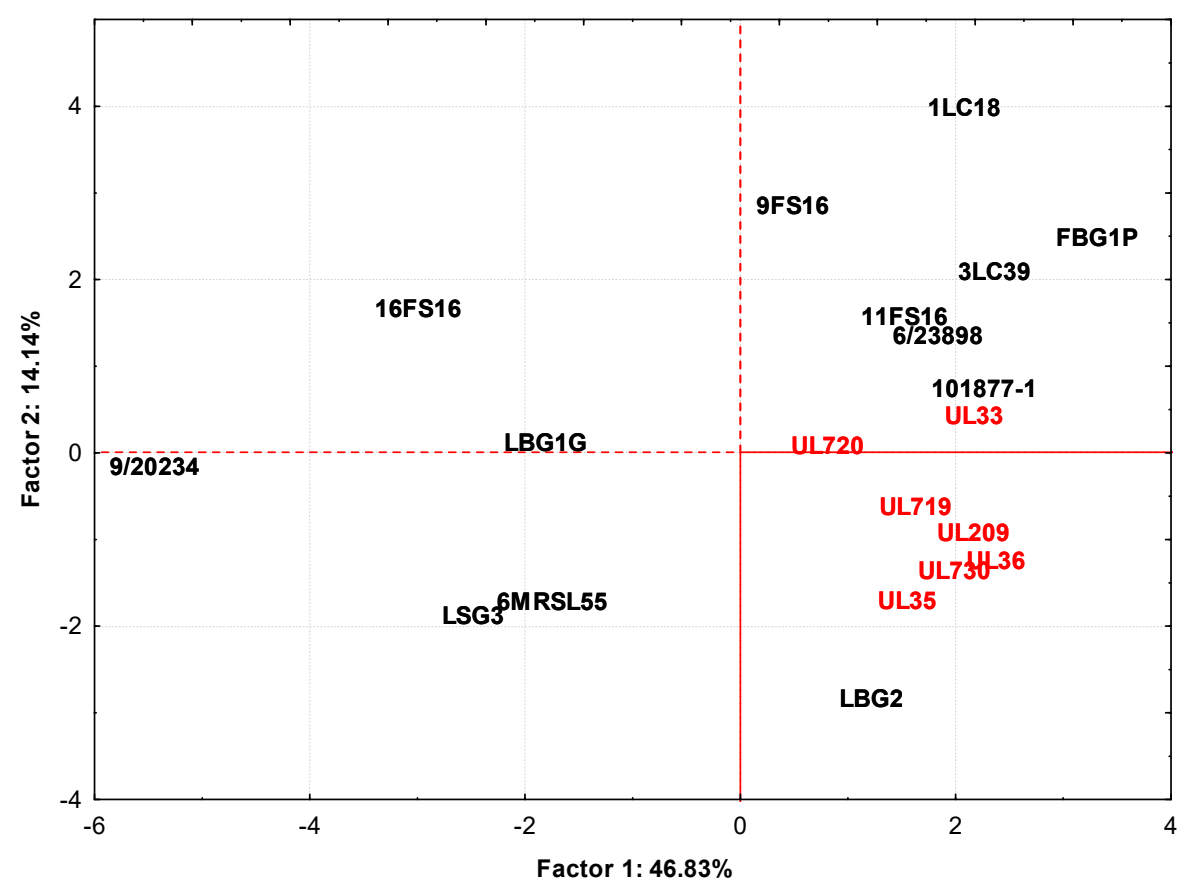

(a)

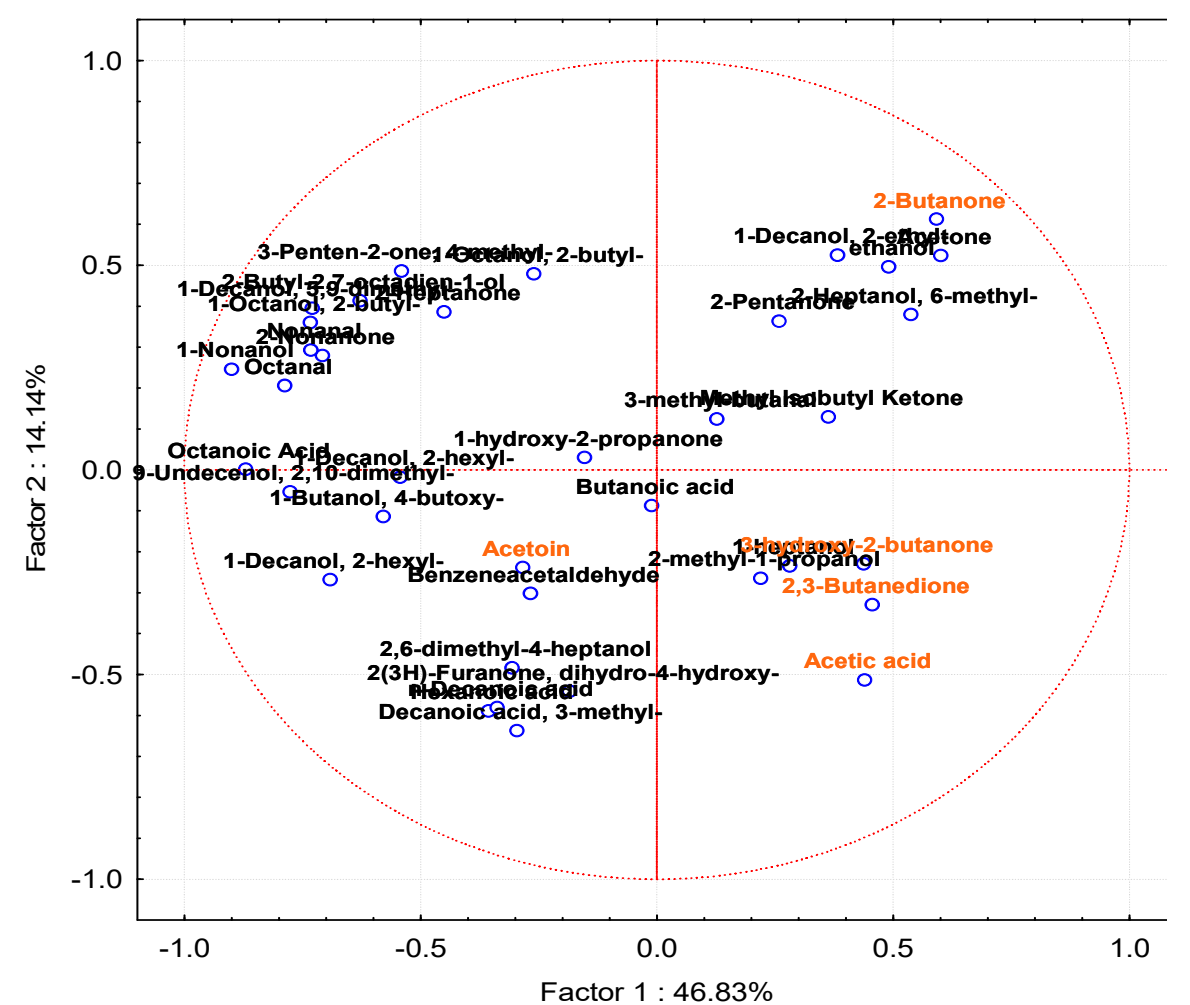

(b)

Figure 6. Distribution of cases $(\mathbf{a})$ and variables $(\mathbf{b})$ on the factor plane $(1 \times 2)$ obtained by samples fermented at $37^{\circ} \mathrm{C}$. Factor 1 and Factor 2 explain $46.83 \%$ and $14.14 \%$ of the total variance, respectively. The sample obtained by strains isolated from Canadian products are highlighted in red. 


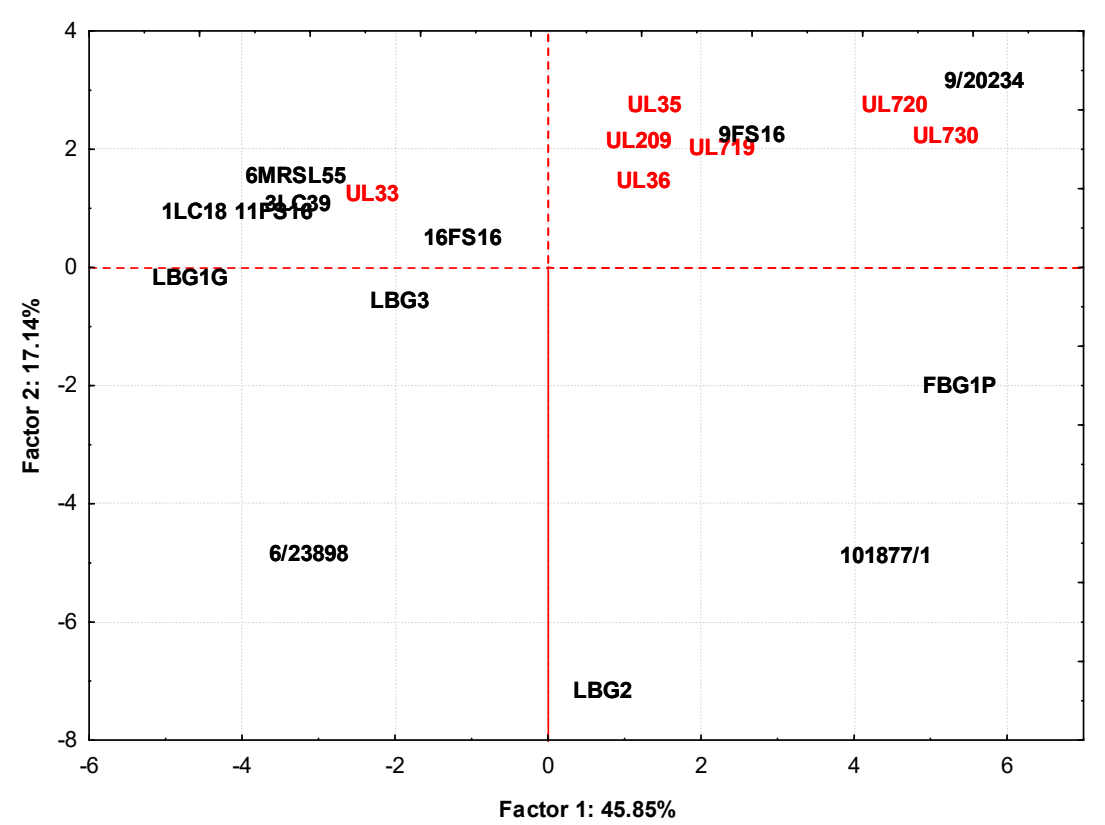

(a)

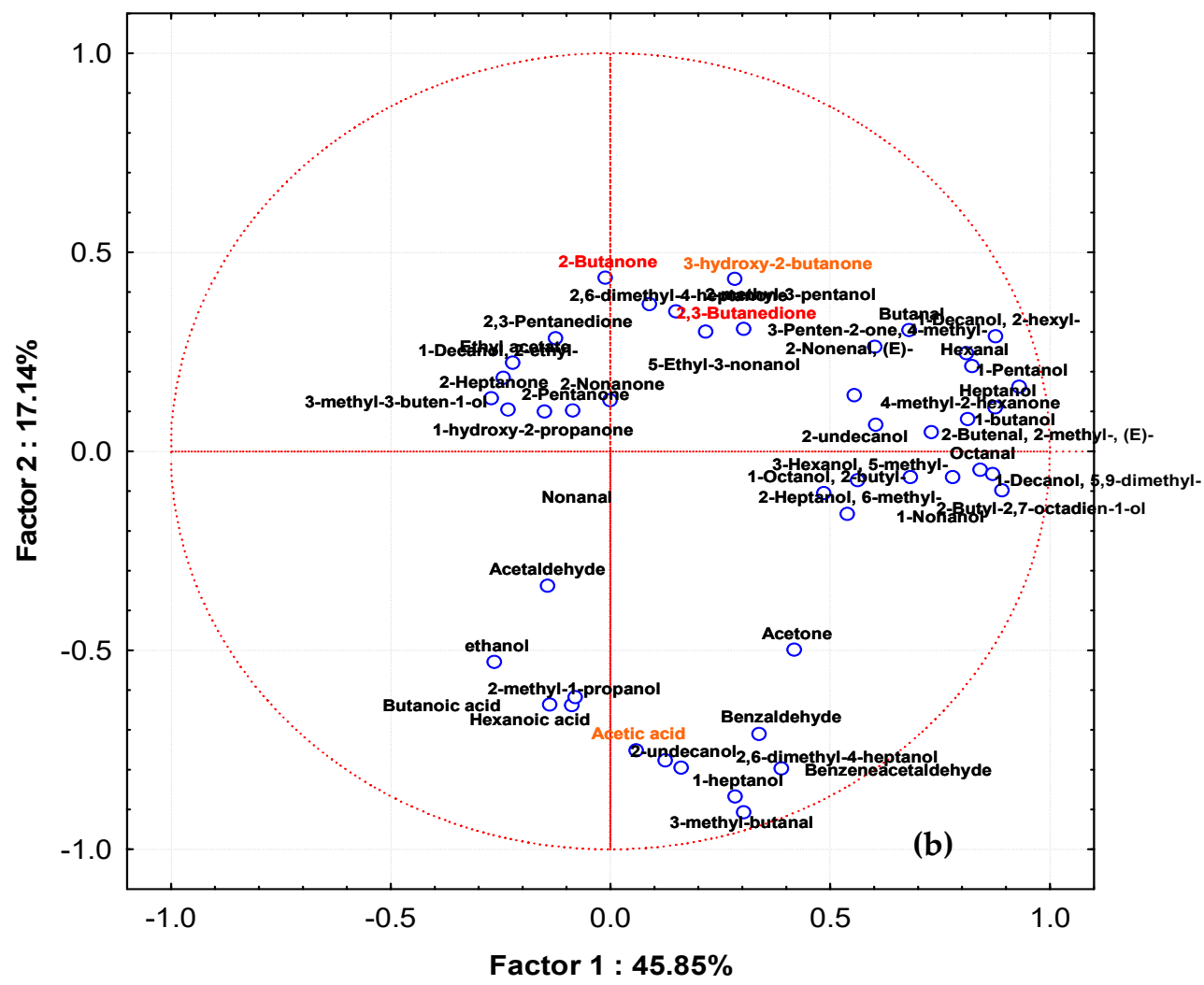

Figure 7. Distribution of cases $(\mathbf{a})$ and variables $(\mathbf{b})$ on the factor plane $(1 \times 2)$ obtained by samples fermented at $30^{\circ} \mathrm{C}$. Factor 1 and Factor 2 explain 45.85 and $17.14 \%$ of the total variance, respectively. The sample obtained by strains isolated from Canadian products are highlighted in red.

Figure $7 \mathrm{a}, \mathrm{b}$ show, respectively, the loading plots of strain cultures in milk at $30^{\circ} \mathrm{C}$ and the volatile compounds produced in the plane defined by principal components 1 (Factor 1) and 2 (Factor 2). In this case, Factor 1 described the $45.85 \%$ variance among samples while Factor 2 accounted for $17.14 \%$. Additionally, in this case, samples obtained by STELA collection, with the exception of UL33, grouped together, including samples from 9/20234 and 9FS16. This group, separated from other strains 
along Factor 1 and Factor 2, was affected by 2,3-butanedione, 3-hydroxy-2-butanone, 2,6 dimethyl heptanone, 4-methyl isobutyl ketone, 5-ethyl-3-nonanol, 2-methyl-3-pentanol, 3-penten-2-one-4-methyl. Samples from LBG2, 101877/1, and FBG1P tended to group together and the compounds affecting this were phenylethyl alcohol, acetone, benzaldehyde, benzenacetaldehyde, 3-methyl butanal, 2,6-dimethyl heptanol. The grouping of the remaining samples (UL33, 6MRSL55, 1LC18, 3LC39, 11FS16, LBG1G, and LBG3) was affected by ethanol, 2-methyl-1-propanol, acetaldehyde, hexanoic acid, and butanoic acid.

\subsection{Nisin Production in Skim Milk at 30 and $37^{\circ} \mathrm{C}$}

The nisin production by the tested strains in skimmed milk, after 12, 24, 48, $72 \mathrm{~h}$ of incubation at 30 and $37^{\circ} \mathrm{C}$, are shown in Figure 8a,b. In general, Lactococci strains produced higher concentration of nisin, expressed as ppm, at $30^{\circ} \mathrm{C}$ rather than $37^{\circ} \mathrm{C}$. According to the data shown in Figure 8a, the Italian strains able to produce the highest nisin values at $30^{\circ} \mathrm{C}$ were $11 \mathrm{FS} 16,101877 / 1$, and LBG2. In particular, these strains produced, respectively, $16 \mathrm{ppm}$ at $48 \mathrm{~h}, 13 \mathrm{ppm}$ at $48 \mathrm{~h}$, and $13.3 \mathrm{ppm}$ at $24 \mathrm{~h}$. The strain $11 \mathrm{FS} 16$ was able to produce at $37^{\circ} \mathrm{C}$ amounts of nisin comparable to those produced at $30^{\circ} \mathrm{C}$ at $48 \mathrm{~h}$. Regarding STELA strains, the strain UL33 (after $24 \mathrm{~h}$ of incubation at $30^{\circ} \mathrm{C}$ ) produced about $10 \mathrm{ppm}$ of nisin, while at $37^{\circ} \mathrm{C}$, analogous production of nisin was delayed up to $48 \mathrm{~h}$. Some of the tested strains (9FS16, FBG1P, 3LC39, and UL33) were able to produce nisin during the incubation at $30{ }^{\circ} \mathrm{C}$ within $6 \mathrm{~h}$ (data not shown). The largest production of nisin, among STELA strains, was reached by the strain UL 209 in $48 \mathrm{~h}$ at $30^{\circ} \mathrm{C}$. After $72 \mathrm{~h}$ of incubation, the concentration of nisin decreased in all the samples.
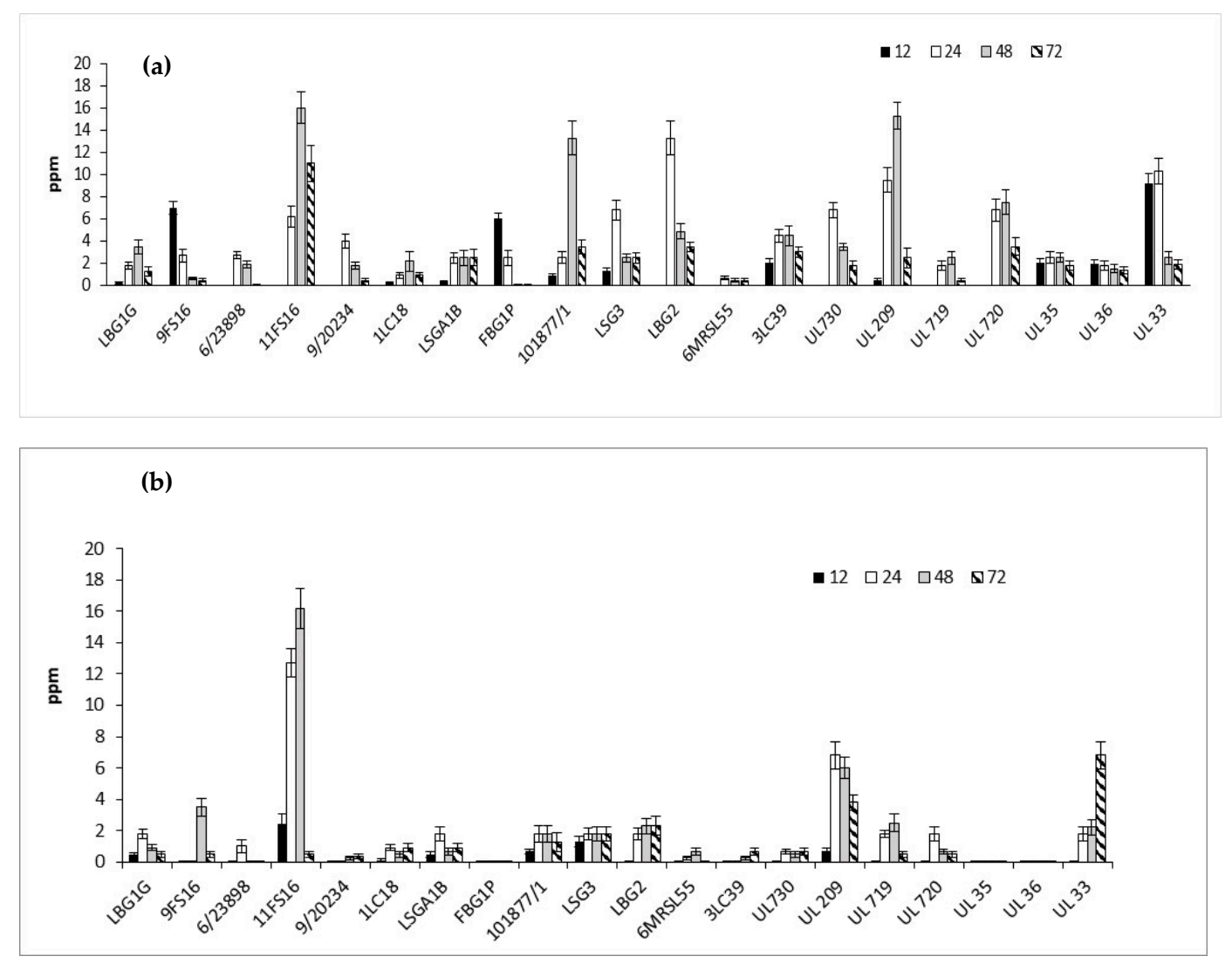

Figure 8. Detection of nisin (expressed as ppm) in milk samples fermented by Italian and Canadian strains at $30(\mathbf{a})$ and $37(\mathbf{b}){ }^{\circ} \mathrm{C}$. 


\subsection{Interaction with Listeria Monocytogenes in Skim Milk at 30 and $37^{\circ} \mathrm{C}$}

The interaction between the tested strains and L. monocytogenes Scott A is reported in Table 2. For each strain tested, inoculated in milk at $6.0 \log \mathrm{cfu} / \mathrm{mL}$, L. monocytogenes was inoculated at the level $4.0 \log \mathrm{cfu} / \mathrm{mL}$ and the viable counts monitored during milk incubation at 30 and $37^{\circ} \mathrm{C}$.

After $24 \mathrm{~h}$ of incubation, the highest reductions in L. monocytogenes were found in the samples inoculated at $30^{\circ} \mathrm{C}$, regardless of the strain used. This data can also be explained by the L. lactis nisin production, which was higher at $30^{\circ} \mathrm{C}$ than at $37^{\circ} \mathrm{C}$. According to the data for the strains $101877 / 1$, 6MRSL55, LSG3, LBG2, 9FS16, FBG1P, 3LC39, UL35, UL36, UL719, UL209, UL720, the inactivation of L. monocytogenes was increased during storage, independently from the incubation temperature but in a strain-dependent way. For the strains LSGA1B, LBG1G, 11FS16, 6/23898, the maximum inactivation was reached between 24 and $48 \mathrm{~h}$, suggesting that some strains have bacteriostatic effects.

Table 2. Values reporting the difference of cell density of Listeria monocytogenes Scott A grown without Lactococcus lactis inoculum and in the presence of L. lactis inoculum. Listeria monocytogenes Scott A was inoculated in milk at a level of $4.0 \mathrm{log} \mathrm{cfu} / \mathrm{mL}$ in relation to the co-inoculated L. lactis strain (about $6.0 \log \mathrm{cfu} / \mathrm{mL}$ ) and the adopted temperature $\left(30\right.$ and $\left.37^{\circ} \mathrm{C}\right)$. For each time considered, the difference was calculated with respect to the control sample represented by L. monocytogenes Scott A, inoculated in milk at a level of $4.0 \log \mathrm{CFU} / \mathrm{mL}$, and incubated at 30 and $37^{\circ} \mathrm{C}$. For each column, samples with a different lowercase letter are significantly different $(p<0.05)$.

\begin{tabular}{|c|c|c|c|c|c|c|c|c|}
\hline Time (h) & 12 h $37^{\circ} \mathrm{C}$ & $12 \mathrm{~h} 30^{\circ} \mathrm{C}$ & $24 \mathrm{~h} 37^{\circ} \mathrm{C}$ & $24 \mathrm{~h} 30^{\circ} \mathrm{C}$ & 48 h $37^{\circ} \mathrm{C}$ & $48 \mathrm{~h} 30^{\circ} \mathrm{C}$ & $72 \mathrm{~h} 37^{\circ} \mathrm{C}$ & $72 \mathrm{~h} 30^{\circ} \mathrm{C}$ \\
\hline $101877 / 1$ & $.2 \pm 0.1^{a}$ & $.3 \pm 0.2^{b}$ & $1.9 \pm 0.3^{a}$ & $-2.5 \pm 0.3^{b}$ & $-4.0 \pm 0.2^{\mathrm{a}}$ & $-3.4 \pm 0.2^{b}$ & $-5.7 \pm 0.3^{a}$ & $-5.0 \pm 0.2^{b}$ \\
\hline LSGA1B & $-0.2 \pm 0.2^{\mathrm{a}}$ & $-0.4 \pm 0.1^{\mathrm{a}}$ & $-2.1 \pm 0.2^{a}$ & $-2.7 \pm 0.1^{b}$ & $-1.7 \pm 0.2^{\mathrm{a}}$ & $-1.7 \pm 0.1^{\mathrm{a}}$ & $-1.6 \pm 0.1^{a}$ & $0.1^{b}$ \\
\hline 6/MRSL55 & $-0.5 \pm 0.2^{a}$ & $-0.3 \pm 0.1^{a}$ & $-0.7 \pm 0.1^{\mathrm{a}}$ & $-1.3 \pm 0.2^{b}$ & $-1.3 \pm 0.1^{\mathrm{a}}$ & $-0.8 \pm 0.2^{b}$ & $-2.6 \pm 0.2^{a}$ & $-1.9 \pm 0.1^{b}$ \\
\hline LSG3 & $-0.6 \pm 0.1^{\mathrm{a}}$ & $-0.9 \pm 0.1^{b}$ & $-0.7 \pm 0.2^{\mathrm{a}}$ & $-1.3 \pm 0.1^{b}$ & $-1.4 \pm 0.2^{\mathrm{a}}$ & $-1.4 \pm 0.2^{\mathrm{a}}$ & $-3.0 \pm 0.1^{a}$ & $-2.4 \pm 0.3^{b}$ \\
\hline LBG2 & $-0.5 \pm 0.1^{\mathrm{a}}$ & $-0.4 \pm 0.1^{\mathrm{a}}$ & $-0.6 \pm 0.1^{\mathrm{a}}$ & $.1^{b}$ & $-3.0 \pm 0.4^{\mathrm{a}}$ & $-2.9 \pm 0.1^{a}$ & $-4.3 \pm 0.2^{\mathrm{a}}$ & $-3.9 \pm 0.2^{a}$ \\
\hline 9FS16 & $-0.9 \pm 0.2^{\mathrm{a}}$ & $-1.4 \pm 0.3^{b}$ & $-2.0 \pm 0.3^{a}$ & $-2.6 \pm 0.1^{b}$ & $-2.6 \pm 0.3^{a}$ & $-2.5 \pm 0.2^{a}$ & $-4.2 \pm 0.3^{a}$ & $-4.0 \pm 0.1^{\mathrm{a}}$ \\
\hline $9 / 20234$ & $-0.4 \pm 0.1^{\mathrm{a}}$ & $-0.5 \pm 0.1^{\mathrm{a}}$ & $-1.5 \pm 0.1^{\mathrm{a}}$ & $-2.5 \pm 0.2^{b}$ & $-2.1 \pm 0.4^{\mathrm{a}}$ & $-2.1 \pm 0.3^{a}$ & $-2.2 \pm 0.1^{a}$ & $0.3^{b}$ \\
\hline LBG1G & $-0.6 \pm 0.3^{a}$ & $-0.4 \pm 0.1^{\mathrm{a}}$ & $-1.7 \pm 0.4^{\mathrm{a}}$ & $-2.4 \pm 0.2^{b}$ & $-2.6 \pm 0.3^{a}$ & $-2.3 \pm 0.3^{a}$ & $-1.6 \pm 0.5^{a}$ & $-1.3 \pm 0.3^{a}$ \\
\hline FBG1P & & & & -3.7 & & $-4.1=$ & & \\
\hline 3LC39 & $-0.8 \pm 0.1^{\mathrm{a}}$ & $-1.3 \pm 0.1^{b}$ & $-2.8 \pm 0.1^{\mathrm{a}}$ & $-3.1 \pm 0.2^{b}$ & $-2.3 \pm 0.3^{a}$ & $-2.9 \pm 0.3^{a}$ & $-4.3 \pm 0.3^{a}$ & $-3.9 \pm 0.2^{\mathrm{a}}$ \\
\hline & & & & & & & & \\
\hline 11 FS16 & $-0.5 \pm 0.1^{\mathrm{a}}$ & $-0.6 \pm 0.2^{\mathrm{a}}$ & $-1.1 \pm 0.1^{\mathrm{a}}$ & $-4.6 \pm 0.3^{b}$ & $-2.3 \pm 0.1^{\mathrm{a}}$ & $-4.2 \pm 0.3^{b}$ & $-3.3 \pm 0.1^{a}$ & $-3.0 \pm 0.1^{\mathrm{a}}$ \\
\hline $6 / 23898$ & $-0.5 \pm 0.2^{\mathrm{a}}$ & $-0.3 \pm 0.1^{\mathrm{a}}$ & $-4.9 \pm 0.3^{a}$ & $-5.1 \pm 0.1^{\mathrm{a}}$ & $-1.3 \pm 0.2^{a}$ & $-1.2 \pm 0.1^{\mathrm{a}}$ & $-1.8 \pm 0.1^{\mathrm{a}}$ & $-1.0 \pm 0.2^{b}$ \\
\hline UL33 & $-0.1 \pm 0.1^{\mathrm{a}}$ & $-1.2 \pm 0.1^{b}$ & $-1.3 \pm 0.4^{\mathrm{a}}$ & $-2.1 \pm 0.1^{b}$ & $-1.7 \pm 0.3^{a}$ & $-2.0 \pm 0.4^{\mathrm{a}}$ & $-2.3 \pm 0.5^{\mathrm{a}}$ & $-2.9 \pm 0.3^{a}$ \\
\hline UL35 & $-0.8 \pm 0.2^{\mathrm{a}}$ & $-1.2 \pm 0.3^{a}$ & $-2.2 \pm 0.1^{\mathrm{a}}$ & $-2.9 \pm 0.3^{b}$ & $-2.5 \pm 0.1^{a}$ & $-3.1 \pm 0.1^{b}$ & $-3.5 \pm 0.3^{a}$ & $-3.3 \pm 0.3^{a}$ \\
\hline UL36 & $-0.6 \pm 0.2^{\mathrm{a}}$ & & $-1.5 \pm 0.1^{\mathrm{a}}$ & $-3.1 \pm 0.3^{b}$ & $-2.2 \pm 0.1^{a}$ & $-3.4 \pm 0.2^{b}$ & $-3.1 \pm 0.2^{a}$ & $-3.9 \pm 0.2^{b}$ \\
\hline UL209 & $-0.6 \pm 0.1^{\mathrm{a}}$ & $-0.5 \pm 0.1^{\mathrm{a}}$ & $-1.4 \pm 0.3^{a}$ & $-2.8 \pm 0.4^{b}$ & $-1.5 \pm 0.4^{\mathrm{a}}$ & $-3.0 \pm 0.2^{b}$ & $-2.7 \pm 0.1^{\mathrm{a}}$ & $-3.1 \pm 0.2^{b}$ \\
\hline UL719 & $-0.9 \pm 0.1^{\mathrm{a}}$ & $-0.7 \pm 0.2^{a}$ & $-1.6 \pm 0.3^{a}$ & $-2.8 \pm 0.2^{b}$ & $-1.3 \pm 0.3^{a}$ & $-3.0 \pm 0.3^{b}$ & $-2.5 \pm 0.3^{a}$ & $-2.9 \pm 0.2^{\mathrm{a}}$ \\
\hline UL720 & $-0.7 \pm 0.2^{\mathrm{a}}$ & $-0.8 \pm 0.1^{\mathrm{a}}$ & $-1.7 \pm 0.3^{a}$ & $-2.8 \pm 0.1^{b}$ & $-1.4 \pm 0.4^{\mathrm{a}}$ & $-2.9 \pm 0.5^{b}$ & $-2.9 \pm 0.2^{a}$ & $-3.7 \pm 0.1^{b}$ \\
\hline UL730 & $-0.8 \pm 0.3^{a}$ & $0.9 \pm 0.1^{\mathrm{a}}$ & $-1.7 \pm 0.1^{a}$ & $-2.8 \pm 0.3^{b}$ & $-1.6 \pm 0.2^{\mathrm{a}}$ & $-3.0 \pm 0.2^{b}$ & $-2.6 \pm 0.1^{\mathrm{a}}$ & $-2.8 \pm 0.3^{a}$ \\
\hline
\end{tabular}

\section{Discussion}

The present research, developed by an exchange project between Italy and Canada-Quebec, focused on the characterization of L. lactis strains in terms of their fermentation capabilities in cow milk, ability to generate good volatile profiles, the nisin production, and the ability to inhibit L. monocytogenes when co-inoculated in milk to select a consortium of strains to be further used for biopreservation in cheese production. The species L. lactis is one of the most import in the dairy industry and it is "generally recognized as safe" (GRAS) [29]. On the other hand, the EU has created a list of microorganisms with a long history of safe use based on a qualified presumption of safety (QPS) in which L. lactis strains are included [30]. In the present study, we focus on this species because it is normally used as starter for Cheddar cheese at $30^{\circ} \mathrm{C}$ and as co-starter for Crescenza cheese at $37^{\circ} \mathrm{C}$. For this reason, the final aim of the exchange project will be the selection of a consortium including L. lactis nisin-producing strains to use as preservation cultures in these dairy productions. The strains were screened for their growth in milk at both the temperatures used in normal cheesemaking protocols. In the present research, all of the strains tested showed good ability to grow in whole cow milk and to decrease the $\mathrm{pH}$ at values 
below 5 within $72 \mathrm{~h}$, independently of the temperature used. This trait could be very important in the case of Crescenza since soft cheese is more affected by bacterial spoilage with respect to ripened ones. Exceptions to this behavior were represented by the strains LBG1G, FBG1P, and ILC18, which decreased the milk pH up to 5.42,5.67, and 5.50, respectively. On the other hand, the considered strains have mesophilic properties, having an optimum growth ranging between 20 and $35^{\circ} \mathrm{C}$. and, thus, most performing at $30^{\circ} \mathrm{C}$ with respect to $37^{\circ} \mathrm{C}$. However, the good potential of these strains' growth is very important since nisin production starts in the early exponential phase of the strains and it is maximized when strains reach the early stationary phase [31]. However, according to the findings of Chaves de Lima et al. [32], viable L. lactis cell loads show that optimal cell growth does not always result in a high bacteriocin titer, as previously reported in studies with this LAB species [33-35]. In fact, the optimum growth also depends on the features of the microorganism used and the environmental settings [36]. The best production of bacteriocins for technological applications in dairy sector remains a challenge.

According to the data obtained by GC/MS/SPME, the strains, inoculated in milk at 30 and $37^{\circ} \mathrm{C}$, generated specific aromagrams. The strains from the STELA collection were able to produce the highest amounts of 2,3-butanedione (diacetyl) and 2-butanone-3-hydroxy (acetoin) in milk when compared with the strains belonging to the University of Bologna and Cagliari. These molecules, with acetaldehyde and 2,3-butanediol, are usually considered as the key aroma of yoghurt- and soft-cheese-like products $[37,38]$ and they can be considered acceptable for products like Crescenza. Particularly, diacetyl, deriving from the citrate metabolism, is an important key molecule of many dairy products since low concentrations impart a creamy and buttery aroma. It also represents a key compound of Camembert, Cheddar, and Emmenthal [39] and soft cheeses [40]. The ability of L. lactis to produce these key aromas is well known, and this is one of the main reasons why it is used at an industrial level [41,42]. In addition, the strains belonging to the Italian collection were able to produce acceptable volatility profiles characterized by ketones and alcohols but lower quantities of diacetyl.

However, it is important to emphasize that the final flavor and aroma of a food product is the result of several interactions between several chemical molecules and sensory receptors, which are affected, in turn, by the food matrix composition and microstructure [25,43].

To select appropriate strains to be used for biopreservation, the production of nisin, for each strain considered, was investigated in skimmed milk. The strains were able to produce the highest amount of nisin at $30{ }^{\circ} \mathrm{C}$ with respect to $37^{\circ} \mathrm{C}$. These data are in agreement with the reference data. In fact, Barman et al. [31] showed that for three strains of L. lactis isolated from buttermilk, the maximum extracellular bacteriocin production took place in MRS medium at $28^{\circ} \mathrm{C}$ with respect to $37^{\circ} \mathrm{C}$. Additionally, Guerra and Castro [44] found that the maximum bacteriocin production for L. lactis subsp. lactis CECT 539, using mussel-processing wastes, was higher at $30^{\circ} \mathrm{C}$ with respect to $37^{\circ} \mathrm{C}$. Additionally, Chaves de Lima et al. [32], by using a central composite design to optimize the production of bacteriocin-like substances from L. lactis, found optimal production at $28^{\circ} \mathrm{C}$ using goat cheese, and at $31{ }^{\circ} \mathrm{C}$ when a probiotic substance was added to the substrate. The challenge test was performed in this research using L. monocytogenes Scott A as a microbial target, since this strain is one of the most studied and applied in vitro studies. Although an additional strain, also from a food source, would need to be tested, contamination with L. monocytogenes is a major alarm in fermented foods. Numerous listeriosis outbreaks have been related to the eating of dairy products, particularly soft cheeses, causing problems for the dairy industry and public health authorities [45]. Despite the fact that most dairy products, especially cheese, are made from pasteurized milk, listeriosis still happens. Moreover, cheese products are ready to eat and are usually stored at refrigeration temperatures, permitting the survival and the growth of psychotropic pathogens. The data regarding the challenge test demonstrated that the highest inactivation of L. monocytogenes Scott A was reached in the presence of the strains 101877/1, LBG2, 9FS16, 11FS16, 3LC39, UL36, UL720, UL35, FBG1P. On the other hand, some of these strains were also able to produce the highest amounts of nisin, especially at $30^{\circ} \mathrm{C}$. Some of these strains produce nisin A, which is reported to be less effective with respect to nisin Z [10]. However, the inactivation of 
L. monocytogenes that was observed can be the result of several factors, including not only the type of nisin produced, but also the amount and the interaction with the system considered. Moreover, other factors, such as the ability of lactic acid bacteria to produce other antimicrobial substances such as lactic acid, hydrogen peroxide, or the competition for the substrate, can explain the highest decrease in L. monocytogenes cell loads observed due to the nisin-Z-producing strains [22]. Additionally, the fast acidification can be a useful tool to inactivate several pathogenic species such as L. monocytogenes $[6,46]$. In this research, the release of nisin production and L. monocytogenes inactivation was performed in milk in order to simulate a real condition as much as possible. In fact, the efficacy of bacteriocins in culture media is not always reproducible in food systems (in situ). In fact, numerous food variables, such as interaction with additives/ingredients, absorption of food components, and inactivation by food enzymes and $\mathrm{pH}$ changes in food, can affect the nisin inhibitory effect and its stability. For example, low solubility and uneven distribution in the food matrix and limited stability of bacteriocin during food shelf life are additional factors that influence the activity of bacteriocins in foods and, consequently, their antimicrobial activity against pathogenic microorganisms.

Additionally, the interaction between bacteriocin/food microbiota can be responsible for changes in the sensitivity to the bacteriocins. Similarly, the physiological state of the microbial target (growing, resting, starving, or viable but non-culturable cells, stressed, or sub-lethally injured cells, endospores), the protection by physical-chemical barriers (microcolonies, biofilms, slime), and the development of resistance/adaptation [47] play an important role in bacteriocins activity. Moreover, even if bacteriocin/s are produced in a sterile milk medium, antagonistic effects against L. monocytogenes are frequently influenced by $\mathrm{pH}$, presence of $\mathrm{NaCl}$, temperature, and other ingredients of the fresh or mature cheese. These factors have an impact on the interaction and absorption of bacteriocin/s to L. monocytogenes [48]. In the present research, most of the samples that were considered showed a marked decrease in the amount of nisin detected over time, independent of the strain considered. This behavior confirms the reference data highlighting that most of nisin production happens in the late exponential growth phase and the beginning of the stationary phase. Afterward, a reduction of the metabolic process leading to the production of the bacteriocin takes place since its biosynthesis is repressed by the bacteriocin accumulation in the growth media [49]. Furthermore, the chemical-physical and compositional features of the substrate are especially able of modifying the stability and activity of the bacteriocin over time. The bacteriocin can interact with other macromolecules present in the substrate, losing its antimicrobial activity $[10,50]$. Furthermore, nisin is disposed to reduction due to its physical diffusion within the food system or its degradation by proteases [51]. These reasons can explain why some strains such as LSGA1B, 9/20234, LBG1G, and 11 FS16 demonstrated more inactivation against L. monocytogenes at $48 \mathrm{~h}$ of incubation rather than $72 \mathrm{~h}$.

\section{Conclusions}

The results that were generated point to the challenge of using some L. lactis strains as bio-control agents in milk. The strains generated specific volatile profiles that show clear differences in fundamental aromatic substances in dairy products such as 2-butanone and diacetyl. In addition, some strains showed that the rapid nisin production started within $12 \mathrm{~h}$ of fermentation, reaching maximum levels between 24 or $48 \mathrm{~h}$, also inhibited and/or reduced the growth of L. monocytogenes Scott A in milk systems. Although other several strains of L. monocytogenes, also from food sources, would need to be tested, this work permitted to select the most promising nisin-producing strains to further use. However, the interaction of L. lactis strains with starters should be carefully studied in future research, especially for producing a cheese like Crescenza, which is created in the presence of thermophilic starters. Strains 3LC39, 101877/1 (producing high level of nisin), LBG2 (producing high level of nisin), 9FS16, UL35, UL36, and UL720 are good candidates as potential bio-control agents for L. monocytogenes in dairy products. However, before being used in cheese production, they need to be tested for a variety of interactions, including with starters, in real conditions. 
Author Contributions: Conceptualization, L.S., I.F., F.P., and R.L.; methodology, L.S., D.B., and F.P.; software, D.B. and M.D.; validation, L.S., Y.Y., and Z.Z.; formal analysis, H.H., L.B.S., S.C., and L.S.; investigation, D.B., M.D., L.S., and F.P.; resources, S.C., F.P., and I.F.; data curation, D.B., L.B.S., and F.P.; writing-original draft preparation, D.B., M.D., and H.H.; writing-review and editing, L.S., L.B.S., S.C., F.P., I.F., and R.L.; visualization, D.B., L.S., H.H., L.B.S., M.D., and S.C.; supervision, F.P., I.F., and R.L.; project administration, F.P. and I.F. All authors have read and agreed to the published version of the manuscript.

Funding: This research received no external funding.

Acknowledgments: The present research is a part of the exchange Project "Potentiel des bactéries lactiques et les levures en tant que cultures bio-protectrices pour les fromages à pâte mole-Utilizzo di batteri lattici e lieviti come colture di biocontrollo in formaggi a breve maturazione", coordinated by Francesca Patrignani, University of Bologna, Italy and Ismail Fliss, University of Laval, Canada. Project code QU17MO02.

Conflicts of Interest: The authors declare no conflict of interest.

\section{References}

1. Fernandez:, B.; Vimont, A.; Desfossés-Foucault, É.; Daga, M.; Arora, G.; Fliss, I. Antifungal activity of lactic and propionic acid bacteria and their potential as protective culture in cottage cheese. Food Control. 2017, 78, 350-356. [CrossRef]

2. Patrignani, F.; Siroli, L.; Serrazanetti, D.I.; Braschi, G.; Betoret, E.; Reinheimer, J.A.; Lanciotti, R. Microencapsulation of functional strains by high pressure homogenization for a potential use in fermented milk. Food Res. Int. 2017, 97, 250-257. [CrossRef] [PubMed]

3. Kondrotiene, K.; Kasnauskyte, N.; Serniene, L.; Gölz, G.; Alter, T.; Kaskoniene, V.; Maruska, A.S.; Malakauskas, M. Characterization and application of newly isolated nisin producing Lactococcus lactis strains for control of Listeria monocytogenes growth in fresh cheese. LWT-Food Sci. Technol. 2018, 87, 507-514. [CrossRef]

4. Dal Bello, B.; Cocolin, L.; Zeppa, G.; Field, D.; Cotter, P.D.; Hill, C. Technological characterization of bacteriocin producing Lactococcus lactis strains employed to control Listeria monocytogenes in Cottage cheese. Int. J. Food Microbiol. 2012, 153, 58-65. [CrossRef]

5. Perin, L.M.; Nero, L.A. Antagonistic lactic acid bacteria isolated from goat milk and identification of a novel nisin variant Lactococcus lactis. BMC Microbiol. 2014, 14, 36. [CrossRef]

6. Siroli, L.; Camprini, L.; Pisano, M.B.; Patrignani, F.; Lanciotti, R. Volatile molecule profiles and anti-listeria monocytogenesactivity of nisin producers lactococcus lactis strains in vegetable drinks. Front. Microbiol. 2019, 10, 563. [CrossRef]

7. Cleveland, J.; Montville, T.J.; Nes, I.F.; Chikindas, M.L. Bacteriocins: Safe, natural antimicrobials for food preservation. Int. J. Food Microbiol. 2001, 71, 1-20. [CrossRef]

8. Egan, K.; Field, D.; Rea, M.C.; Ross, R.P.; Hill, C.; Cotter, P.D. Bacteriocins: Novel solutions to age old spore-related problems? Front. Microbiol. 2016, 7, 1497-1505. [CrossRef]

9. Mills, S.; Serrano, L.M.; Griffin, C.; O'Connor, P.M.; Schaad, G.; Bruining, C.; Hill, C.; Ross, R.P.; Meijer, W.C. Inhibitory activity of Lactobacillus plantarum LMG P-26358 against Listeria innocua when used as an adjunct starter in the manufacture of cheese. Microb. Cell Fact. 2011, 10, S7. [CrossRef]

10. Silva, C.C.G.; Silva, S.P.M.; Ribeiro, S.C. Application of bacteriocins and protective cultures in dairy food preservation. Front. Microbiol. 2018, 9, 594. [CrossRef]

11. Zendo, T. Screening and characterization of novel bacteriocins from lactic acid bacteria. Biosci. Biotechnol. Biochem. 2013, 77, 893-899. [CrossRef] [PubMed]

12. Gharsallaoui, A.; Oulahal, N.; Joly, C.; Degraeve, P. Nisin as a Food Preservative: Part 1: Physicochemical Properties, Antimicrobial Activity, and Main Uses. Crit. Rev. Food Sci. Nutr. 2016, 56, 1262-1274. [CrossRef] [PubMed]

13. Settanni, L.; Corsetti, A. Application of bacteriocins in vegetable food biopreservation. Int. J. Food Microbiol. 2008, 121, 123-138. [CrossRef] [PubMed]

14. Yang, E.; Fan, L.; Jiang, Y.; Doucette, C.; Fillmore, S. Antimicrobial activity of bacteriocin-producing lactic acid bacteria isolated from cheeses and yogurts. AMB Express 2012, 2, 48. [CrossRef] [PubMed]

15. Zhao, L.; Wang, S.; Liu, F.; Dong, P.; Huang, W.; Xiong, L.; Liao, X. Comparing the effects of high hydrostatic pressure and thermal pasteurization combined with nisin on the quality of cucumber juice drinks. Innov. Food Sci. Emerg. Technol. 2013, 17, 27-36. [CrossRef] 
16. Grosu-Tudor, S.S.; Stancu, M.M.; Pelinescu, D.; Zamfir, M. Characterization of some bacteriocins produced by lactic acid bacteria isolated from fermented foods. World J. Microbiol. Biotechnol. 2014, 30, 2449-2459. [CrossRef]

17. Biscola, V.; Todorov, S.D.; Capuano, V.S.C.; Abriouel, H.; Gálvez, A.; Franco, B.D.G.M. Isolation and characterization of a nisin-like bacteriocin produced by a Lactococcus lactis strain isolated from charqui, a Brazilian fermented, salted and dried meat product. Meat Sci. 2013, 93, 607-613. [CrossRef]

18. Benech, R.O.; Kheadr, E.E.; Laridi, R.; Lacroix, C.; Fliss, I. Inhibition of Listeria innocua in cheddar cheese by addition of nisin $\mathrm{Z}$ in liposomes or by in situ production in mixed culture. Appl. Environ. Microbiol. 2002, 68, 3683-3690. [CrossRef]

19. Lanciotti, R.; Chaves-López, C.; Patrignani, F.; Paparella, A.; Guerzoni, M.E.; Serio, A.; Suzzi, G. Effects of milk treatment with dynamic high pressure on microbial populations, and lipolytic and proteolytic profiles of Crescenza cheese. Int. J. Dairy Technol. 2004, 57, 19-25. [CrossRef]

20. Nieto-Arribas, P.; Seseña, S.; Poveda, J.M.; Palop, L.; Cabezas, L. Genotypic and technological characterization of Lactococcus lactis isolates involved in processing of artisanal Manchego cheese. J. Appl. Microbiol. 2009, 1505-1517. [CrossRef]

21. Siroli, L.; Patrignani, F.; Serrazanetti, D.I.; Parolin, C.; Palomino, R.A. ñahu.; Vitali, B.; Lanciotti, R. Determination of antibacterial and technological properties of vaginal lactobacilli for their potential application in dairy products. Front. Microbiol. 2017, 8, 166. [CrossRef] [PubMed]

22. Siroli, L.; Patrignani, F.; Serrazanetti, D.I.; Vannini, L.; Salvetti, E.; Torriani, S.; Gardini, F.; Lanciotti, R. Use of a nisin-producing Lactococcus lactis strain, combined with natural antimicrobials, to improve the safety and shelf-life of minimally processed sliced apples. Food Microbiol. 2016, 54, 11-19. [CrossRef]

23. Bravo, D.; Rodríguez, E.; Medina, M. Nisin and lacticin 481 coproduction by Lactococcus lactis strains isolated from raw ewes' milk. J. Dairy Sci. 2009, 92, 4805-4811. [CrossRef] [PubMed]

24. De Vos, W.M.; Mulders, J.W.M.; Siezen, R.J.; Hugenholtz, J.; Kuipers, O.P. Properties of nisin Z and distribution of its gene, nisZ, in Lactococcus lactis. Appl. Environ. Microbiol. 1993, 59, 213-218. [CrossRef] [PubMed]

25. Patrignani, F.; Serrazanetti, D.I.; Mathara, J.M.; Siroli, L.; Gardini, F.; Holzapfel, W.H.; Lanciotti, R. Use of homogenisation pressure to improve quality and functionality of probiotic fermented milks containing Lactobacillus rhamnosus BFE 5264. Int. J. Dairy Technol. 2016, 69, 262-271. [CrossRef]

26. Pongtharangkul, T.; Demirci, A. Evaluation of agar diffusion bioassay for nisin quantification. Appl. Microbiol. Biotechnol. 2004, 65, 268-272. [CrossRef]

27. Millette, M.; Le Tien, C.; Smoragiewicz, W.; Lacroix, M. Inhibition of Staphylococcus aureus on beef by nisin-containing modified alginate films and beads. Food Control. 2007, 18, 878-884. [CrossRef]

28. de Oliveira Junior, A.A.; Silva de Araújo Couto, H.G.; Barbosa, A.A.T.; Carnelossi, M.A.G.; de Moura, T.R. Stability, antimicrobial activity, and effect of nisin on the physico-chemical properties of fruit juices. Int. J. Food Microbiol. 2015, 211, 38-43. [CrossRef]

29. Wessels, S.; Axelsson, L.; Bech Hansen, E.; De Vuyst, L.; Laulund, S.; Lähteenmäki, L.; Lindgren, S.; Mollet, B.; Salminen, S.; Von Wright, A. The lactic acid bacteria, the food chain, and their regulation. Trends Food Sci. Technol. 2004, 15, 498-505. [CrossRef]

30. Introduction of a Qualified Presumption of Safety (QPS) Approach for Assessment of Selected Microorganisms Referred to EFSA-Opinion of the Scientific Committee. EFSA J. 2007, 5, 587.

31. Barman, S.; Ghosh, R.; Mandal, N.C. Production optimization of broad spectrum bacteriocin of three strains of Lactococcus lactis isolated from homemade buttermilk. Ann. Agrar. Sci. 2018, 16, 286-296. [CrossRef]

32. de Lima, E.L.C.; de Moura Fernandes, J.; Cardarelli, H.R. Optimized fermentation of goat cheese whey with Lactococcus lactis for production of antilisterial bacteriocin-like substances. LWT_Food Sci. Technol. 2017, 84, 710-716. [CrossRef]

33. Gutiérrez-Cortés, C.; Suarez, H.; Buitrago, G.; Nero, L.A.; Todorov, S.D. Enhanced Bacteriocin Production by Pediococcus pentosaceus 147 in Co-culture With Lactobacillus plantarum LE27 on Cheese Whey Broth. Front. Microbiol. 2018, 9, 2952. [CrossRef] [PubMed]

34. Furtado, D.N.; Todorov, S.D.; Landgraf, M.; Destro, M.T.; Franco, B.D.G.M. Bacteriocinogenic Lactococcus lactis subsp. Lactis DF04MI isolated from goat milk: Characterization of the bacteriocin. Braz. J. Microbiol. 2014, 45, 1541-1550. [CrossRef]

35. Liu, X.; Chung, Y.K.; Yang, S.T.; Yousef, A.E. Continuous nisin production in laboratory media and whey permeate by immobilized Lactococcus lactis. Process. Biochem. 2005, 40, 13-24. [CrossRef] 
36. Panesar, P.S.; Kennedy, J.F.; Gandhi, D.N.; Bunko, K. Bioutilisation of whey for lactic acid production. Food Chem. 2007, 105, 1-14. [CrossRef]

37. Cheng, H. Volatile flavor compounds in yogurt: A review. Crit. Rev. Food Sci. Nutr. 2010, 50, 938-950. [CrossRef]

38. Durlu-Özkaya, F.; Gün, İ. Aroma Compounds of Some Traditional Turkish Cheeses and Their Importance for Turkish Cuisine. Food Nutr. Sci. 2014, 5, 425-434. [CrossRef]

39. Clark, S.; Winter, C.K. Diacetyl in Foods: A Review of Safety and Sensory Characteristics. Compr. Rev. Food Sci. Food Saf. 2015, 14, 634-643. [CrossRef]

40. Milesi, M.M.; Wolf, I.V.; Bergamini, C.V.; Hynes, E.R. Two strains of nonstarter lactobacilli increased the production of flavor compounds in soft cheeses. J. Dairy Sci. 2010, 93, 5020-5031. [CrossRef]

41. Ho, V.T.T.; Lo, R.; Bansal, N.; Turner, M.S. Characterisation of Lactococcus lactis isolates from herbs, fruits and vegetables for use as biopreservatives against Listeria monocytogenes in cheese. Food Control. 2018, 85, 472-483. [CrossRef]

42. Passerini, D.; Laroute, V.; Coddeville, M.; Le Bourgeois, P.; Loubière, P.; Ritzenthaler, P.; Cocaign-Bousquet, M.; Daveran-Mingot, M.L. New insights into Lactococcus lactis diacetyl- and acetoin-producing strains isolated from diverse origins. Int. J. Food Microbiol. 2013, 160, 329-336. [CrossRef] [PubMed]

43. Lanciotti, R.; Vannini, L.; Patrignani, F.; Iucci, L.; Vallicelli, M.; Ndagijimana, M.; Guerzoni, M.E. Effect of high pressure homogenisation of milk on cheese yield and microbiology, lipolysis and proteolysis during ripening of Caciotta cheese. J. Dairy Res. 2006, 73, 216-226. [CrossRef] [PubMed]

44. Pérez Guerra, N.; Pastrana Castro, L. Production of bacteriocins from Lactococcus lactis subsp. lactis CECT 539 and Pediococcus acidilactici NRRL B-5627 using mussel-processing wastes. Biotechnol. Appl. Biochem. 2002, 36, 119-125. [CrossRef] [PubMed]

45. Melo, J.; Andrew, P.W.; Faleiro, M.L. Listeria monocytogenes in cheese and the dairy environment remains a food safety challenge: The role of stress responses. Food Res. Int. 2015, 67, 75-90. [CrossRef]

46. Filannino, P.; Cardinali, G.; Rizzello, C.G.; Buchin, S.; De Angelis, M.; Gobbetti, M.; Di Cagno, R. Metabolic responses of Lactobacillus plantarum strains during fermentation and storage of vegetable and fruit juices. Appl. Environ. Microbiol. 2014, 80, 2206-2215. [CrossRef] [PubMed]

47. Gálvez, A.; López, R.L.; Abriouel, H.; Valdivia, E.; Omar, N. Ben Application of bacteriocins in the control of foodborne pathogenic and spoilage bacteria. Crit. Rev. Biotechnol. 2008, 28, 125-152. [CrossRef] [PubMed]

48. Vera Pingitore, E.; Todorov, S.D.; Sesma, F.; Gombossy de Melo Franco, B.D. Application of bacteriocinogenic Enterococcus mundtii CRL35 and Enterococcus faecium ST88Ch in the control of Listeria monocytogenes in fresh Minas cheese. Food Microbiol. 2012, 32, 38-47. [CrossRef]

49. Abbasiliasi, S.; Tan, J.S.; Tengku Ibrahim, T.A.; Bashokouh, F.; Ramakrishnan, N.R.; Mustafa, S.; Ariff, A.B. Fermentation factors influencing the production of bacteriocins by lactic acid bacteria: A review. RSC Adv. 2017, 7, 29395-29420. [CrossRef]

50. Fernández-Pérez, R.; Sáenz, Y.; Rojo-Bezares, B.; Zarazaga, M.; Rodríguez, J.M.; Torres, C.; Tenorio, C.; Ruiz-Larrea, F. Production and Antimicrobial Activity of Nisin Under Enological Conditions. Front. Microbiol. 2018, 9, 1918. [CrossRef]

51. Sarkar, P.; Bhunia, A.K.; Yao, Y. Impact of starch-based emulsions on the antibacterial efficacies of nisin and thymol in cantaloupe juice. Food Chem. 2017, 217, 155-162. [CrossRef] [PubMed]

Publisher's Note: MDPI stays neutral with regard to jurisdictional claims in published maps and institutional affiliations.

(C) 2020 by the authors. Licensee MDPI, Basel, Switzerland. This article is an open access article distributed under the terms and conditions of the Creative Commons Attribution (CC BY) license (http://creativecommons.org/licenses/by/4.0/). 